\title{
Composition of the ichthyofauna in Brazilian semiarid reservoirs
}

\author{
Silvia Yasmin Lustosa Costa ${ }^{1}$, José Etham de Lucena Barbosa ${ }^{1}$,Leandro Gomes Viana ${ }^{I}$ \& Telton Pedro Anselmo Ramos ${ }^{2,3^{*}}$ \\ ${ }^{1}$ Departamento de Ciências Biológicas e da Saúde, Universidade Estadual da Paraiba, Campina Grande, PB, Brazil \\ ${ }^{2}$ Departamento de Botânica, Ecologia e Zoologia, Universidade Federal do Rio Grande do Norte, Natal, RN, Brazil \\ ${ }^{3}$ Departamento de Sistemática e Ecologia, Universidade Federal da Paraíba, João Pessoa, PB, Brazil \\ *Corresponding author: Telton Pedro Anselmo Ramos, e-mail: telton@gmail.com
}

COSTA, S.Y.L., VIANA, L.G., BARBOSA, J. E. L., RAMOS, T.P.A. Composition of the ichthyofauna in Brazilian semiarid reservoirs. Biota Neotropica. 17(3): e20170334. http://dx.doi.org/10.1590/1676-0611-BN-2017-0334

\begin{abstract}
The scale of impact that the São Francisco River transposition project will have on the drainage basins ichthyofauna is still unclear, however, changes in the fish community diversity and abundance is probable. Surveys and registries of the fish fauna within key systems of the catchment basins are priority actions for the conservation of the aquatic diversity. This study conducted a taxonomic survey of the Epitácio Pessoa (Boqueirão municipality) and Argemiro de Figueiredo (Itatuba municipality), reservoirs ichthyofauna, both belonging to the Paraíba do Norte River basin, important socioeconomic and environmental systems for the transposition project. Monthly sampling was carried out between October/2014 to September/2015 in the upstream and downstream zones of the reservoirs. The specimens were collected using dip nets, drag nets, and sieves, and placed on ice in the field. Later in the laboratory, they were transferred to $10 \%$ formaldehyde and then preserved in $70 \%$ alcohol. A total of 2,328 specimens were collected representing five orders, 14 families, and 31 species in both systems. At the upstream zones 2057 specimens were collected representing 17 species, and at the downstream zones 271 specimens were collected representing 24 species. Of the 31 species recorded, 13 species are endemic to watersheds that drain rivers from the Brazilian semi-arid region, and seven species (Apareiodon davisi, Characidium bimaculatum, Hypostomus pusarum, Parotocinclus jumbo, P. spilosoma, Pimelodella enochi, and Prochilodus brevis) are endemic to the Mid-Northeastern Caatinga Ecoregion (MNCE). Among the latter, Parotocinclus spilosoma and Pimelodella enochi are endemic to the Paraíba do Norte River. Apareiodon davisi is classified as Endangered according to the current published Brazil's official list of endangered species of fish and aquatic invertebrates. This pre-transposition ichthyofaunistic survey will serve as a basis for future post-transposition analyzes, considering this action will change the scope of the ecosystems diversity.
\end{abstract}

Keywords: Endemism, Paraíba, Basins Transposition.

\section{Composição da ictiofauna em reservatórios do semiárido brasileiro}

Resumo: A dimensão do impacto que a transposição do rio São Francisco provocará na ictiofauna das bacias receptoras ainda é imprecisa, entretanto, é provável que haja alterações na riqueza e abundância da comunidade de peixes. Levantamentos e registros prévios da fauna íctica em sistemas chaves das bacias receptoras são ações prioritárias para a conservação da diversidade aquática. Este estudo realizou o levantamento taxonômico da ictiofauna dos reservatórios Epitácio Pessoa (município de Boqueirão), e Argemiro de Figueiredo (município Itatuba), ambos pertencentes a bacia hidrográfica do rio Paraíba do Norte, estado da Paraíba, importantes sistemas sócioeconômicos e ambientais para o projeto da transposição. Assim, foram realizadas amostragens mensais de Outubro/2014 a Setembro/2015 nas zonas lacustres e a jusante dos reservatórios. Os espécimes foram coletados com redes de espera, tarrafa, arrasto, peneiras e puçás, em seguida acondicionados em gelo no campo, posteriormente no laboratório, transferidos para o formol a 10\% e conservados em álcool $70 \%$. Foram coletados um total de 2328 espécimes distribuídas em 31 espécies, 14 famílias e cinco ordens nos dois sistemas. Nas zonas lacustres foram coletados 2057 espécimes distribuídos em 17 espécies e nas áreas a jusantes foram coletados 271 indivíduos, distribuídos em 24 espécies. Das 31 espécies registradas, 13 são endêmicas das bacias hidrográficas que drenam rios do semiárido brasileiro, destas, sete (Apareiodon davisi, Characidium bimaculatum, Hypostomus pusarum, Parotocinclus jumbo, P. spilosoma, Pimelodella enochi e Prochilodus brevis) são endêmicas do Nordeste Médio Oriental. Dentre estas últimas, $P$. spilosoma e P. enochi são endêmicas do rio Paraíba do Norte. Apareiodon davisi é classificada como Em Perigo de acordo com a atual lista oficial de espécies ameaçadas de peixes e invertebrados aquáticos no Brasil. Este levantamento ictiofaunístico pré-transposição servirá de base para análises futuras pós-transposição, considerando que esta ação acarretará mudanças no âmbito de diversidade dos ecossistemas em questão.

Palavras-chave: Endemismo, Paraíba, Transposição de bacias. 


\section{Introduction}

Approximately 5,160 freshwater fish species are described from South America, representing 20 orders, 69 families, and 739 genera (Reis et al. 2016). Brazil covers majority of the Neotropical region, and its ichthyofauna consists of more than 3,000 freshwater species (Reis et al. 2016). According to Buckup et al. 2007, the number of freshwater fish species described in Brazil has increased significantly in recent years, with an annual growth greater than $20 \%$, an average never yet recorded. However, the knowledge about the Brazilian ichthyofaunistic diversity is focused within certain regions, with the Northeast region displaying the lowest volume of published studies and a limited number of researchers (Rosa \& Menezes 1996, Langeani et al. 2009, Ramos et al. 2014).

The lack of accurate knowledge related to systematics and distribution of fish taxa within Northeast Brazil is one of the main aspects limiting the ichthyofaunistic diversity evaluation and fish biogeographic determination of this region (Rosa et al. 2003, Ramos et al. 2014). However, in recent decades the number of research articles related to the ichthyofauna diversity of Brazilian semi-arid region has increased (Ramos et al. 2005, Novaes et al. 2013, Sánchez-Botero et al. 2013, Gurgel-Lourenço et al. 2013, Silva et al. 2014, Ramos et al. 2014, Silva et al. 2015, Gurgel-Lourenço et al. 2015).

In Brazil, approximately $12 \%$ of its territory is classified as being semi-arid with a population of about 23 million inhabitants (INSA 2015). Thus, the aquatic ecosystems are fundamental to the survival of local communities, taking into account that the construction of dams was primarily intended to increase water storage capacity for the urban network (Maltchik 1996, Rebouças et al. 2006, Medeiros et al. 2010).

Currently, Northeast region of Brazil is undergoing the process of channel construction that will transport water from the largest hydrographic basin in the region, the São Francisco River basin, to the basins of the Mid-Northeastern Caatinga Ecoregion - MNCE (ecoregion composed of hydrographic basins located between the São Francisco and Parnaíba basins - Rosa et al. 2003), among which is the Paraíba do Norte River basin. The Paraíba do Norte River watershed is the third largest of this ecoregion. In order to contribute to the knowledge of this systems ichthyofauna prior to the commencement of the transposition project, an ichthyofauna survey was undertaken focusing on two large reservoirs of the Paraíba do Norte River basin, the Epitácio Pessoa and the Argemiro de Figueiredo reservoirs, and their respective downstream areas.

\section{Material and Methods}

\section{Study area}

The study was carried out in the Epitácio Pessoa (Boqueirão) and Argemiro de Figueiredo (Acauã) reservoirs and their respective downstream areas. These reservoirs are situated in the Paraíba do Norte River basin, in Paraíba State (Figures 1 and 2). The Paraíba do Norte River is about $360 \mathrm{~km}$ in length, rising above a thousand meters elevation in the Serra de Jabitacá in Monteiro municipality, and flows into the Atlantic Ocean in Cabedelo
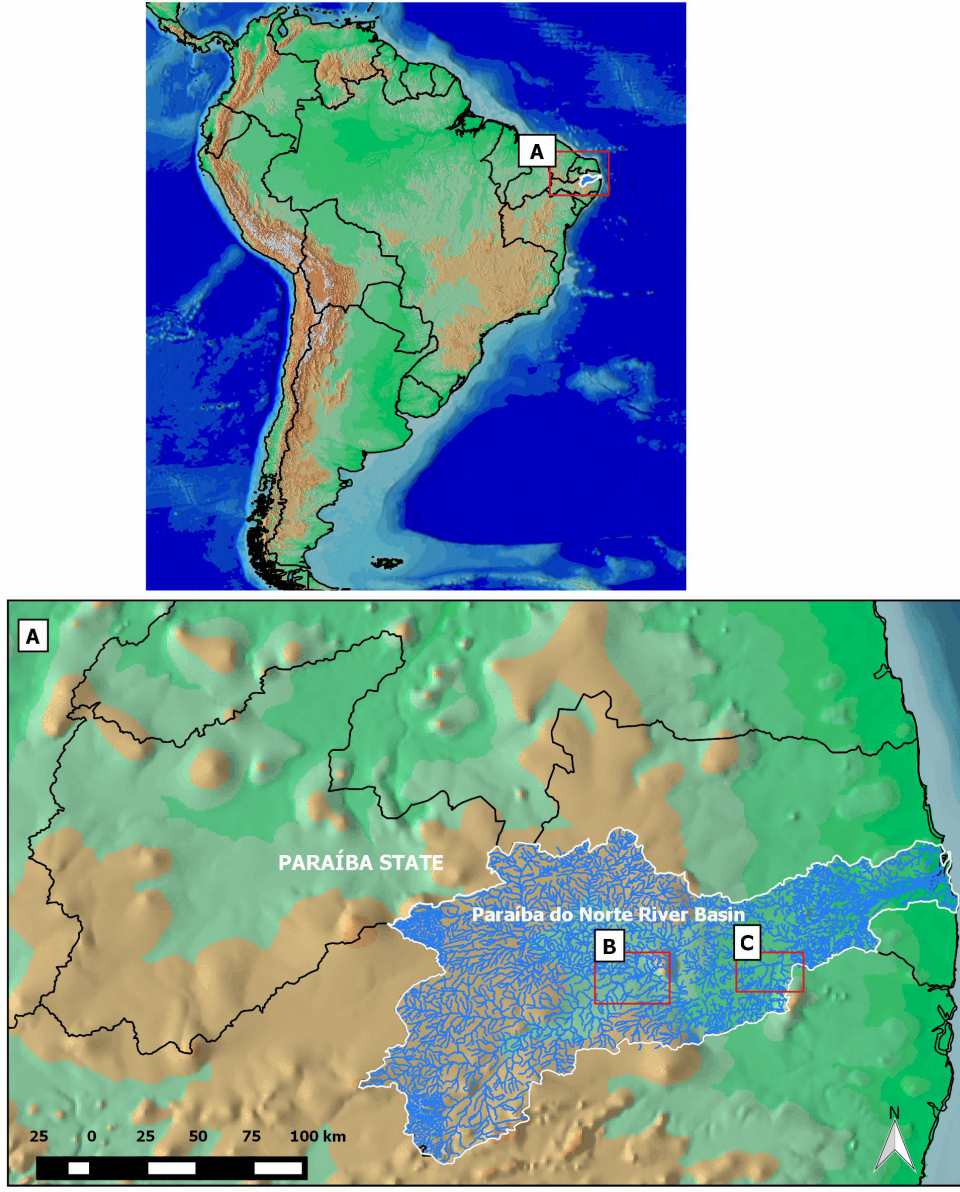
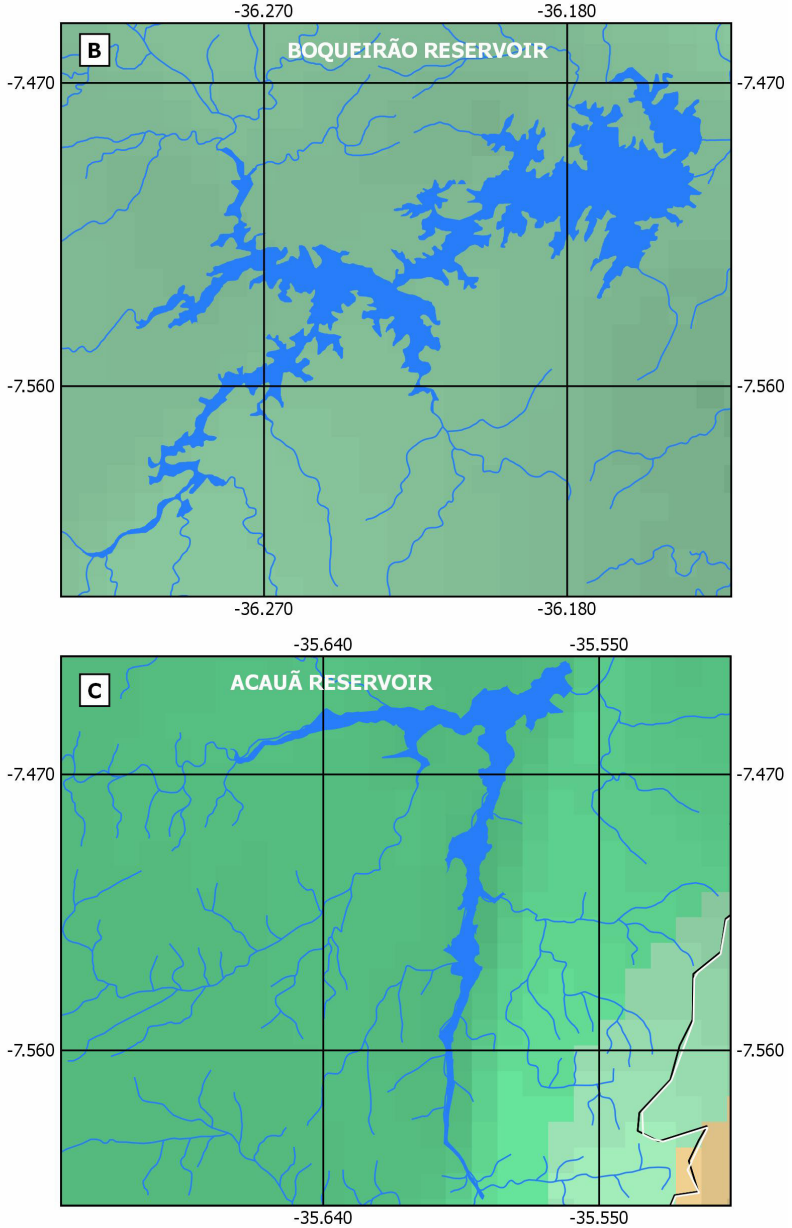

Figure 1. Map of Paraíba do Norte River basin (A): Boqueirão (B) and Acauã (C) reservoirs. 


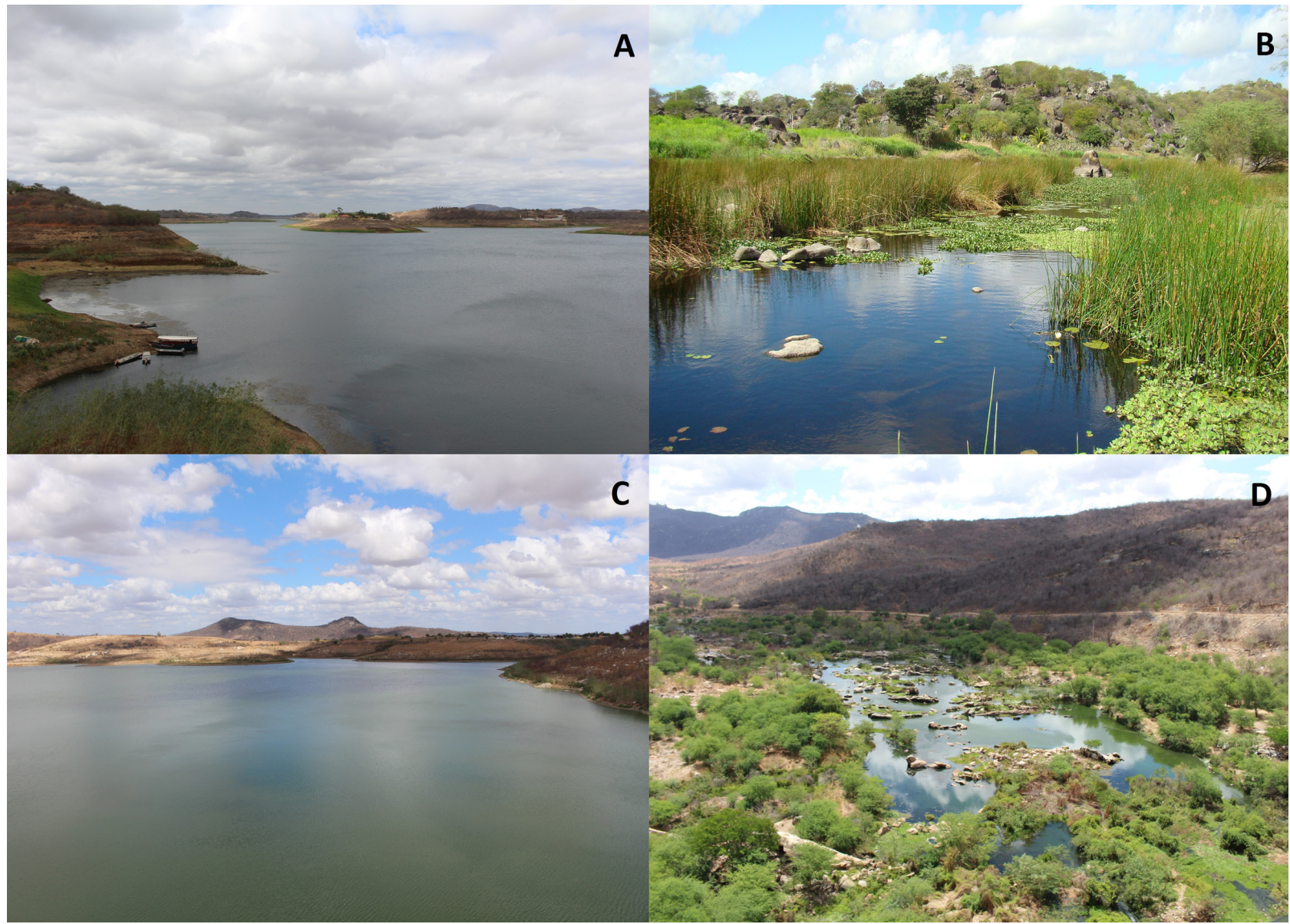

Figure 2. Epitácio Pessoa Reservoir (A) and its downstream area (B), Argemiro de Figueiredo Reservoir (C) and its downstream area (D).

municipality. The basin comprises an area of 20,071.83 $\mathrm{km}^{2}$, making it the second largest in Paraíba State. It has five main reservoirs, among them are the Epitácio Pessoa and Argemiro de Figueiredo (Paraíba 2007).

The Epitácio Pessoa reservoir ( $7^{\circ} 29^{\prime} 20^{\prime \prime} \mathrm{S}$ and $\left.36^{\circ} 17^{\prime} 3^{\prime \prime} \mathrm{W}\right)$, popularly known as Boqueirão, is located in the upper basin at Boqueirão municipality in the northeastern semi-arid region. It is the largest and main reservoir of the Paraíba do Norte River basin with a maximum capacity of $411,686.287 \mathrm{~m}^{3}$ and covering an area of about $14,000 \mathrm{~km}^{2}$, supplying water to 26 municipalities in Paraíba State. Its main uses are human supply (approximately 600,000 people), animal husbandry and irrigation (Silva 1987, AESA 2015).

The Argemiro de Figueiredo reservoir, commonly known as Acauã, is located in the middle course of the Paraíba do Norte River between the geographical coordinates $7^{\circ} 36^{\prime} 51$ ' $\mathrm{S}$ and $35^{\circ} 33^{\prime} 01^{\prime \prime} \mathrm{W}$ in Itatuba municipality, supplying several cities as well as irrigation, water for livestock, and aquaculture. This reservoir has an area of 1,725 hectares with a $253,144,247 \mathrm{~m}^{3}$ of accumulation capacity (SEMARH 2006).

\section{Sampling}

Sampling in the Epitácio Pessoa and Argemiro de Figueiredo Reservoirs was conducted monthly for one year, between October/2014 and September/2015. In addition, the downstream ebbing (environments that usually have a lotic regime) areas of the reservoirs were also sampled. In Argemiro de Figueiredo reservoir, the specimens were collected using a trawl net (20 $\mathrm{m}$ long, $2 \mathrm{~m}$ high and $10 \mathrm{~mm}$ mesh), cast net $(2.4 \mathrm{~m}$ high, and $12 \mathrm{~mm}$ mesh) and gill nets ( $10 \mathrm{~m}$ long and 35, 45 and $55 \mathrm{~mm}$ meshes).
Epitácio Pessoa specimens were collected by means of gill nets only. Gill nets were set at dusk and retrieved at dawn, having a soaking time of 12 hours in each of the sampled environments. Additional sampling methods were used when sampling downstream of the two reservoirs, including the use of sieves, grips and a trawl net $(4 \mathrm{~m}$ long, $2 \mathrm{~m}$ high, and $5 \mathrm{~mm}$ mesh). Specimens collected in the reservoirs were placed on ice and taken to the Universidade Estadual da Paraíba (UEPB). Majority of the material was used for feeding studies, and the remaining specimens together with the material collected from the downstream areas were treated according to the scientific curatorial standards, by fixing the specimens in formaldehyde for two to eight days, then transferring them to a $70^{\circ}$ GL ethyl alcohol solution, and labeling and sorting specimens into lots according to Malabarba \& Reis (1987).

Specimen sampling and identifications were carried out at the Laboratório de Ecologia Aquática da Universidade Estadual da Paraíba (LEAQ/UEPB), Laboratório de Sistemática e Morfologia de Peixes da Universidade Federal da Paraíba (LASEP/UFPB) and Laboratório de Ictiologia Sistemática e Evolutiva da Universidade Federal do Rio Grande do Norte (LISE/UFRN). After identification, specimens were deposited in the Ichthyological collections at the UFPB (29 lots) and UFRN (two lots).

Meristic and morphometric data involved in the identification process were obtained according to Hubbs \& Lagler (2006). Species identification was performed according to specialized literature (e.g., Kullander 1983, Britski et al. 1984, Vari 1989, Castro \& Vari 2004, Ramos 2012). Taxonomic classification and endemism of species followed Eschmeyer et al. (2017) and Rosa et al. (2003), respectively. 


\section{Data analysis}

Species occurrence was analyzed according to occurrence frequency (FO in percentage) of the species against evaluation criteria for values: Very common (FO > 70\%); Common (FO between 50\% and 70\%); Uncommon (FO between $10 \%$ and $50 \%$ ) and Rare (FO $<10 \%)$.

To evaluate abundance of each species, total number of species captured was considered and relative abundance of each species was obtained by dividing the number of individuals captured from each species by total number of specimens.

\section{Results}

A total of 2,057 specimens were collected in the Epitácio Pessoa and Argemiro de Figueiredo Reservoirs, representing freshwater fish from three orders, 10 families, 16 genera, and 17 species (Table 1). In the Argemiro de

Table 1. List of fish species recognized in Argemiro Figueiredo (AF) and Epitácio Pessoa (EP) reservoirs and their respective downstream areas (DAF) and (DEP), Paraíba do Norte River basin, Northeastern Brazil with their respective names. Endemic: endemism in Caatinga biome; Allochthonous: introduced from other regions; Autochthonous: native to the region; Exotic: introduced from other countries.

\begin{tabular}{|c|c|c|c|c|c|c|c|}
\hline Taxon & Popular name & Origin & $\mathbf{A F}$ & EP & DAF & DEP & Voucher \\
\hline \multicolumn{8}{|l|}{ CHARACIFORMES } \\
\hline \multicolumn{8}{|l|}{ Crenuchidae } \\
\hline Characidium bimaculatum Fowler, 1941 & "Filhote de traíra" & Endemic & & & $\mathrm{X}$ & & UFPB-10631 \\
\hline \multicolumn{8}{|l|}{ Erythrinidae } \\
\hline Hoplias cf. malabaricus (Bloch, 1794) & "Traíra" & Autochthonous & $\mathrm{X}$ & $\mathrm{X}$ & $\mathrm{X}$ & $\mathrm{X}$ & UFPB-10604 \\
\hline \multicolumn{8}{|l|}{ Parodontidae } \\
\hline Apareiodon davisi Fowler, 1941 & "Piau" & Endemic & $\mathrm{X}$ & & & $\mathrm{X}$ & UFPB-10601 \\
\hline \multicolumn{8}{|l|}{ Anostomidae } \\
\hline Leporinus piau Fowler, 1941 & "Piau" & Endemic & $\mathrm{X}$ & $\mathrm{X}$ & $\mathrm{X}$ & $\mathrm{X}$ & UFPB -10606 \\
\hline \multicolumn{8}{|l|}{ Curimatidae } \\
\hline Psectrogaster rhomboides Eigenmann \& Eigenmann, 1889 & "Cumatã" & Endemic & & & & & UFPB-10607 \\
\hline Steindachnerina notonota (Miranda Ribeiro, 1937) & "Piaba" & Endemic & & & $\mathrm{X}$ & $\mathrm{X}$ & UFPB-10616 \\
\hline \multicolumn{8}{|l|}{ Prochilodontidae } \\
\hline Prochilodus brevis Steindachner, 1875 & "Curimatã" & Endemic & $\mathrm{X}$ & $\mathrm{X}$ & $\mathrm{X}$ & $\mathrm{X}$ & UFPB - 10608 \\
\hline \multicolumn{8}{|l|}{ Triportheidae } \\
\hline Triportheus signatus (Garman, 1890) & "Sardinha" & Endemic & $\mathrm{X}$ & $\mathrm{X}$ & $\mathrm{X}$ & $\mathrm{X}$ & UFPB-10600 \\
\hline \multicolumn{8}{|l|}{ Characidae } \\
\hline Astyanax aff. bimaculatus (Linnaeus, 1758) & "Piaba" & Autochthonous & $\mathrm{X}$ & $\mathrm{X}$ & $\mathrm{X}$ & $\mathrm{X}$ & UFPB -10603 \\
\hline Astyanax aff. fasciatus (Cuvier, 1819) & "Piaba" & Autochthonous & $\mathrm{X}$ & $\mathrm{X}$ & $\mathrm{X}$ & & UFPB-10635 \\
\hline Compsura heterura Eigenmann, 1915 & "Piaba" & Autochthonous & & & $\mathrm{X}$ & & UFPB-10627 \\
\hline Hemigrammus rodwayi Durbin, 1909 & "Piaba" & Autochthonous & & & $\mathrm{X}$ & & UFPB-10632 \\
\hline Hemigrammus marginatus Ellis, 1911 & "Piaba" & Autochthonous & & & $\mathrm{X}$ & & UFPB-10630 \\
\hline Serrapinnus heterodon (Eigenmann, 1915) & "Piaba" & Autochthonous & & & $\mathrm{X}$ & & UFPB-10634 \\
\hline Hyphessobrycon parvellus Ellis, 1911 & "Piaba" & Autochthonous & & & $\mathrm{X}$ & & UFPB-10633 \\
\hline \multicolumn{8}{|l|}{ SILURIFORMES } \\
\hline \multicolumn{8}{|l|}{ Heptapteridae } \\
\hline Pimelodella enochi Fowler, 1941 & "Cascudo" & Endemic & & & $\mathrm{X}$ & $\mathrm{X}$ & UFRN-0443 \\
\hline Rhamdia quelen (Quoy \& Gaimard, 1824) & “Jundiá" & Autochthonous & & & $\mathrm{X}$ & & UFPB- 10625 \\
\hline \multicolumn{8}{|l|}{ Loricariidae } \\
\hline Hypostomus pusarum (Starks, 1913) & “Cascudo" & Endemic & $\mathrm{X}$ & $\mathrm{X}$ & & $\mathrm{X}$ & UFPB-10602 \\
\hline Parotocinclus jumbo Britski \& Garavello, 2002 & "Cascudinho" & Endemic & & & $\mathrm{X}$ & & UFPB-10628 \\
\hline Parotocinclus spilosoma (Fowler, 1941) & "Cascudinho" & Endemic & & & & $\mathrm{X}$ & UFRN-0731 \\
\hline \multicolumn{8}{|l|}{ CYPRINODONTIFORMES } \\
\hline \multicolumn{8}{|l|}{ Poeciliidae } \\
\hline Poecilia reticulata Peters, 1859 & "Barrigudinho", & Allochthonous & & & $\mathrm{X}$ & & UFPB-10629 \\
\hline Poecilia vivipara Bloch \& Schneider, 1801 & "Barrigudinho" & Autochthonous & & & $\mathrm{X}$ & $\mathrm{X}$ & UFPB-10626 \\
\hline \multicolumn{8}{|l|}{ SYNBRANCHIFORMES } \\
\hline \multicolumn{8}{|l|}{ Synbranchidae } \\
\hline Synbranchus aff. marmoratus Bloch, 1795 & "Mussum" & Autochthonous & & & $\mathrm{X}$ & & UFPB-10623 \\
\hline \multicolumn{8}{|l|}{ PERCIFORMES } \\
\hline \multicolumn{8}{|l|}{ Sciaenidae } \\
\hline Plagioscion squamosissimus (Heckel, 1840) & "Pescada" & Allochthonous & $\mathrm{X}$ & $\mathrm{X}$ & & & UFPB-9983 \\
\hline \multicolumn{8}{|l|}{ Cichlidae } \\
\hline Astronotus ocellatus (Agassiz, 1831) & “Óscar” & Allochthonous & & $\mathrm{X}$ & & & UFPB-10605 \\
\hline Cichla ocellaris Bloch \& Schneider 1801 & “Tucunaré” & Allochthonous & & $\mathrm{X}$ & & & UFPB-10609 \\
\hline Cichlasoma orientale Kullander, 1983 & "Corró preto" & Endemic & & & $\mathrm{X}$ & $\mathrm{X}$ & UFPB-9951 \\
\hline Crenicichla menezesi (Ploeg, 1991) & "Quatro-olho" & Endemic & $\mathrm{X}$ & $\mathrm{X}$ & $\mathrm{X}$ & $\mathrm{X}$ & UFPB-9980 \\
\hline Geophagus brasiliensis (Boulenger, 1897) & "Acará" & Autochthonous & $\mathrm{X}$ & $\mathrm{X}$ & $\mathrm{X}$ & $\mathrm{X}$ & UFPB-9952 \\
\hline Oreochromis niloticus (Linnaeus, 1758) & "Tilápia-do-Nilo" & Exotic & $\mathrm{X}$ & $\mathrm{X}$ & & & UFPB-9985 \\
\hline Coptodon rendalli (Boulenger, 1897) & “Tilápia" & Exotic & $\mathrm{X}$ & $\mathrm{X}$ & & & UFPB-2883 \\
\hline
\end{tabular}


Figueiredo Reservoir a total of 1,482 specimens were collected, representing 13 species and in the Epitácio Pessoa reservoir a total of 575 specimens were collected, belonging to 16 species. Of the 17 species recorded, 12 species were common to both reservoirs, one species, Apareiodon davisi, was recorded only in the Argemiro Figueiredo Reservoir, and four species in the Epitácio Pessoa Reservoir: Astronotus ocellatus, Cichlasoma orientale, Cichla ocellaris, and Psectrogaster rhomboides.

Characiformes and Perciformes showed the highest species richness in the reservoir ichthyofauna, both with eight species $(47.1 \%)$ of the 17 species registered. However, five species of the order Perciformes were introduced: Astronotus ocellatus, Cichla ocellaris, Oreochromis niloticus, Coptodon rendalli, and Plagioscion squamosissimus. Species from the order Characiformes were distributed within seven families and seven genera, and those species from the order Perciformes were distributed within two families and eight genera. The order Siluriformes, within the reservoirs, was represented by only one species (Hypostomus pusarum).

Cichlidae was family with the highest species richness in the Epitácio Pessoa and Argemiro Figueiredo Reservoirs, representing 41,1\% with seven species. However, this family comprised only three species $(17.7 \%)$ when allochthonous and exotic species are removed from this account, this is also the case of the Characidae family. Oreochromis niloticus (exotic species) was most abundant species, representing a total of with $473(23 \%)$ specimens collected, and Plagioscion squamosissimus (allochthonous species) was second most abundant species, representing a total of $430(21 \%)$ collected specimens. Astyanax aff. bimaculatus was the most abundant among the native species, representing a total of 189 (9\%) collected specimens, followed by Geophagus brasiliensis with a total of $172(8 \%)$ collected specimens. Cichlidae and Sciaenidae were the families with highest relative abundance values, comprising $45 \%$ and $21 \%$, respectively, of all sampling of the two reservoirs. It is important to note that Sciaenidae family was represented by only one species, Plagioscion squamosissimus. Other families had a relative abundance percentage below $10 \%$. Perciformes was the most abundant order in the Epitácio Pessoa and Argemiro de Figueiredo Reservoirs, representing a total of 1,372 (67\%) collected specimens, followed by Characiformes with a total of $598(29 \%)$ specimens and Siluriformes with a total of 87 (4\%) specimens.

Analysis of frequency of occurrence (FO\%) in the Argemiro de Figueiredo reservoir showed that six species were classified as "Very
Common", four species as "Common", two species as "Uncommon" and one species as "Rare" (Table 2). For the Epitácio Pessoa Reservoir, five species were classified as "Very Common", six species as "Common", four species as "Uncommon" and a single species as "Rare" (Table 2).

In the lotic portion of the river downstream from Argemiro de Figueiredo and Epitácio Pessoa reservoirs, 271 specimens were collected and represented 24 species, 20 genera, 11 families, and five freshwater fish orders (Table 1). Additional species were recorded through downstream sampling but these were not recognized within the reservoirs. In the area downstream of Epitácio Pessoa Reservoir, 12 species were recorded in which five species were not collected in the reservoir: Apareiodon davisi, Steindachnerina notonota, Parotocinclus spilosoma, Pimelodella enochi, and Poecilia vivipara. In the area downstream of Argemiro de Figueiredo Reservoir, 20 species were recorded in which 11 species were not collected in the reservoir: Characidium bimaculatum, Compsura heterura, Hyphessobrycon cf. parvellus, Hemigrammus marginatus, Hemigrammus rodwayi, Parotocinclus jumbo, Poecilia reticulata, Rhamdia quelen, Serrapinnus heterodon, Steindachnerina notonota, and Synbranchus aff. marmoratus. In these two downstream areas, 12 families were recognized but seven of these families bear only one species.

A total of 31 species were collected in Argemiro Figueiredo and Epitácio Pessoa Reservoirs and their downstream areas, distributed within 27 genera, 14 families, and five orders (Table 1). Characiformes was the order with the largest species richness, comprising 15 species within 13 genera and eight families, and representing $48 \%$ of recorded species (Figure $3 \mathrm{~A}$ ). Perciformes was the second richest order with eight species recognized within eight genera and two families, and representing 26\% of recorded species. Characidae and Cichlidae were families with the highest number of species, both with seven species representing $23 \%$ of species sampled, followed by Loricariidae with three (10\%) species (Figure 3B).

\section{Discussion}

The dams built in the intermittent rivers of Brazilian Northeast region serve as a refuge for freshwater fishes during drought periods. The number of species (17) recorded in the two reservoirs in our study is in accordance to other reservoirs in the region. Gurgel-Lourenço et al. (2013) also listed 17 species from Paulo Sarasate and Edson Queiroz Reservoirs, both located

Table 2. Occurrence Frequency Classification (F.O.\%) for species from Epitácio Pessoa (EP) and Argemiro de Figueiredo (AF) Reservoirs.

\begin{tabular}{|c|c|c|c|c|c|c|}
\hline \multirow{2}{*}{ Species } & \multicolumn{3}{|c|}{ EP } & \multicolumn{3}{|c|}{ AF } \\
\hline & $\mathbf{N}$ & FO (\%) & Classification & N2 & FO (\%) & Classification \\
\hline Hoplias cf. malabaricus & 45 & 100 & Very common & 9 & 50 & Common \\
\hline Astronotus ocellatus & 34 & 91,6 & Very common & - & - & - \\
\hline Cichla ocellaris & 53 & 83,3 & Very common & - & - & - \\
\hline Prochilodus brevis & 52 & 83,3 & Very common & 2 & 8,33 & Rare \\
\hline Geophagus brasiliensis & 52 & 75 & Very common & 120 & 83,3 & Very common \\
\hline Leporinus piau & 54 & 66,6 & Common & 6 & 41,6 & Uncommon \\
\hline Psectrogaster romboides & 19 & 66,6 & Common & - & - & - \\
\hline Hypostomus pusarum & 63 & 58,3 & Common & 24 & 50 & Common \\
\hline Triportheus signatus & 58 & 58,3 & Common & 29 & 83,3 & Very common \\
\hline Cichlasoma orientale & 19 & 50 & Common & - & - & - \\
\hline Crenicichla menezesi & 11 & 50 & Common & 149 & 100 & Very common \\
\hline Oreochromis niloticus & 67 & 41,6 & Uncommon & 406 & 100 & Very common \\
\hline Astyanax aff. bimaculatus & 34 & 25 & Uncommon & 155 & 50 & Common \\
\hline Plagioscion squamosissimus & 8 & 25 & Uncommon & 422 & 100 & Very common \\
\hline Coptodon rendalli & 5 & 25 & Uncommon & 23 & 50 & Common \\
\hline Astyanax aff. fasciatus & 1 & 8,3 & Rare & 30 & 16,6 & Uncommon \\
\hline Apareiodon davisi & - & - & - & 104 & 75 & Very common \\
\hline
\end{tabular}



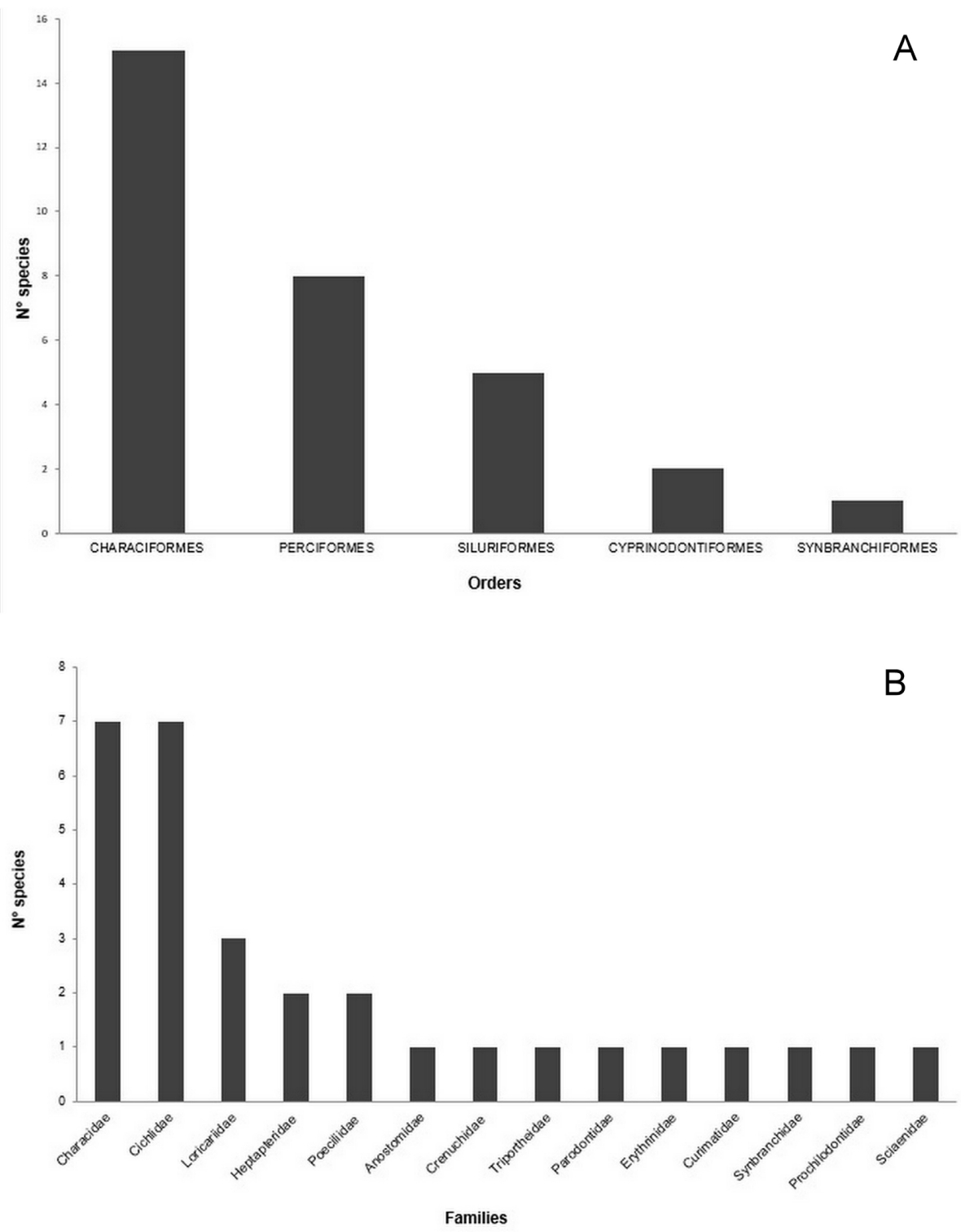

Figure 3. Fish species richness by Order (A) and Family (B) collected in Argemiro Figueiredo and Epitácio Pessoa reservoirs and their respective downstream areas.

in Ceará State. Sánchez-Botero et al. (2013) recognized 9 species by conducting monthly samplings for a period of six months in Santo Anastácio Reservoir at Ceará State. Silva-Filho et al. (2011) recorded 14 species in Duas Unas reservoir, review at Jaboatão River basin, Pernambuco State. Marinho et al. (2006) recognized seven species in Namorados (municipality of São João do Cariri) and Soledade (Soledade municipality) reservoirs at Paraíba do Norte River basin, which are under the hydrographic domain of Taperoá sub-basin. Montenegro et al. (2012) listed 11 species for Taperoá II reservoir, located in Taperoá municipality at Paraíba do Norte River basin. Our study supports a much higher number of species when compared to these previous studies in the same basins.

Characiformes and Siluriformes generally present the greatest species richness Neotropical regions (Lowe-McConnel 1987, Reis et al. 2003), as well as in Brazil (Buckup et al. 2007). The proportional richness of the order Characiformes has been a natural tendency of ichthyofauna basins under influence of the Caatinga biome (Ramos et al. 2005, Silva et al. 2014, Ramos et al. 2014, Silva et al. 2015). The Characidae family, one of the richest families in this study, generally has the greatest richness in fish diversity in Northeast Brazil (Ramos et al. 2005, Paiva et al. 2014,
Silva et al. 2014, Ramos et al. 2014, Silva et al. 2015). Rosa et al. (2003) observed that Characidae was the most diversified family (50 species) when studied the diversity of Caatinga ichthyofauna. Most of its species are associated to inland waters of Brazil (Britski 1972).

However, order Perciformes displays higher species diversity than the order Siluriformes when it comes to reservoirs (Marinho et al. 2006, Montenegro et al. 2012, Sánchez-Botero et al. 2013, Gurgel-Lourenço et al. 2015). The higher species diversity of the order Perciformes in the semiarid reservoirs can be correlated to the lentic habit of Caatinga reservoirs, to which Cichlidae species, the most diverse family within the order, are well adapted (Kullander 2003, Langeani et al. 2007). Whereas species of the order Siluriformes are adapted to running water (lotic) environments (Nelson 2006). Epitácio Pessoa and Argemiro de Figueiredo Reservoirs as well as other Caatinga reservoirs are lentic environments that are more suitable for the predominance of cichlids. Most of the exotic species within the Caatinga rivers belong to the Cichlidae family, as pointed out in our results previously that noticed five out of eight Cichlidae species were introduced in these two reservoirs. 
Oreochromis niloticus, popularly known as "Nile tilapia", is an exotic species that is well established in the Brazilian semiarid region and the most abundant species recorded in Epitácio Pessoa and Argemiro de Figueiredo Reservoirs. This species feeds mainly on phytoplankton and zooplankton, and it has great trophic plasticity and it is highly tolerant to environmental variations (Gurgel \& Fernando 1994, Starling et al. 2002, Attayde et al. 2007). The abundance of Oreochromis niloticus is related to breeding in tanks from Argemiro Figueiredo Reservoir where 406 out of 473 specimens were collected. In addition to competition for food resources, mostly zooplankton, this species may affect other species through changes in habitat quality. Omnivorous filter-feeding fish such as tilapia tend to increase total phytoplankton biomass through predation on zooplankton and nutrient recycling (Drenner et al. 1996, Attayde et al. 2007).

Plagioscion squamosissimus, the second most abundant species, was introduced in reservoirs in Northeast Brazil during the early 1950s by Departamento Nacional de Obras Contra a Seca (DNOCS). However, fisheries were only productive from 1970s onwards (Fontenele \& Peixoto 1978, Sato \& Godinho 1999). Introduction of exotic species is considered to be one of the major reasons for biodiversity loss and the second major cause of animal extinction (Fontana et al. 2003, Ziller \& Zalba 2007). Exotic fish may act as predators, competitors or even disseminate pathogenic organisms (Reis et al. 2003).

Astyanax aff. bimaculatus is a native species, is the third most abundant representative in the two reservoirs, along with other small Characidae species, popularly known as "piabas" in Northeastern Brazil, that is generally the most abundant group in the region (Ramos 2012, Paiva et al. 2014, Silva et al. 2014). These species are not valuable for fisheries purposes due to their relatively small size (Ramos 2012). However, these species are of importance as a food source for carnivorous species (Câmara et al. 1991). The relative low frequency of "piabas" in these reservoirs, and particularly in Epitácio Pessoa reservoir, when compared to Oreochromis niloticus and Plagioscion squamosissimus may be related to the abundance of Cichla ocellaris and Hoplias cf. malabaricus. The latter two species, such as P. squamosissimus, are considered top predators that have piscivorous habits and feed on small whole fishes such as "piabas" when adults (Goldstein 1973, Lowe-McConnell 1975, Peixoto 1982, Lowe-McConnell 1987, Resende et al. 1996, Almeida et al. 1997, Bennemann \& Shibatta, 2002.).

Apareiodon davisi, one of the most representative species in our survey, was collected in Argemiro de Figueiredo Reservoir only, and registered during most of the sampling period. Species of the genus Apareiodon are generally found in habitats characterized by flowing water with high oxygen concentrations and rocky substrates, typical of lotic environments. Most of its species are found in rapids, and scrape rock-adhered algae off rocks as their food source (Pavanelli 2006). However, A. davisi was one of the six most abundant species from Argemiro de Figueiredo Reservoir, which leads us to infer that a population of this species is adapted to lentic conditions that are distinctive of this reservoir.

Apareiodon davisi is endemic to the Mid-Northeastern Caatinga ecoregion and it was described from specimens collected in drainages of Jaguaribe, Piranhas-Açu, and Paraíba do Norte rivers by Rodolfo Von Ihering during the decade of 1930 in Ceará and Paraíba States (Fowler, 1941). Apareiodon davisi is the only threatened species among those herein recognized, according to the criteria from the Brazil's official list of endangered species of fish and aquatic invertebrates (Brasil, 2014), due to the following aspects: 1) recent records detected reduction of population size. In the decades of 1940 and 1950, samples of $A$. davisi were abundant (around 100 specimens collected). However, recent expeditions have shown a decrease in the number of collected specimens (less than 10 specimens). Additionally, a single specimen has been recently collected in the type locality of $A$. davisi (b iv), in the North Paraíba River basin, with few additional specimens collected in recent years; 2) continuous decline of habitat quality (b iii). The locations in which $A$. davisi has been registered have suffered anthropogenic impacts such as deforestation due to expansions of sugar cane farming and extensive livestock, erosion, and river siltation. In addition, the main basins where this species is recognized are characterized by an intermittent regime and will receive water from the San Francisco River transposition. The consequences of changes in the hydrological regime (intermittent to perennial) are unknown to A. davisi. 3) severe fragmentation of its populations (a). Uninterrupted dams contribute to population fragmentation in the basins where $A$. davisi are registered. Population regressions were not yet quantified for this species, but occupation area (AOO) together with current records of this species were calculated as $93,9 \mathrm{Km}^{2}$ (B2), which categorize $A$. davisi as "endangered (EN)", according to B2 ab (iii,iv) criteria (Brasil, 2014).

Characiformes and Siluriformes, and the families Characidae, Loricariidae, and Cichlidae in the downstream area of Epitácio Pessoa and Argemiro de Figueiredo reservoirs were the most representative groups, which is in agreement with other studies from Northeast Brazil such as those by Ramos et al. (2005), Silva et al. (2014), Ramos et al. (2014), Silva et al. (2015). These results, however, differed regarding ichthyofauna within the reservoirs, as mentioned above.

Poecilia reticulata is the only species considered as introduced into the region that was not recorded within the two reservoirs among 24 species recognized in the downstream area of Argemiro de Figueiredo and Epitácio Pessoa Reservoirs. This is a small and well-disseminated species in Northeast Brazil, commonly used for aquarium trading and as pest control (Ramos 2012).

Two new occurrences were recorded from Paraíba do Norte River basin: Hemigrammus rodwayi Durbin, 1909, previously known from Guyana, Suriname, French Guiana Rivers and the Amazon basin; and Hyphessobrycon cf. parvellus Ellis, 1911 known from the coastal drainage of Bahia State, Brazil (Reis et al. 2003, Buckup et al. 2007). The occurrence of Hemigrammus rodwayi in the Brazilian Northeast is considered natural due to environmental similarities between the ichthyofauna of these regions as mentioned in Agassiz \& Agassiz (1938) and Paiva (1978). Hyphessobrycon cf. parvellus was previously recorded from São Francisco River basin and its distribution is now extended to the MNCE. Both Hemigrammus rodwayi and Hyphessobrycon cf. parvellus were collected in several coastal rivers of Northeastern Brazil (Telton Ramos, personal communication).

Six species out of 31 species recorded in the present study were introduced, and 25 autochthonous species (Figures 4 and 5) in which 13 species $(52 \%)$ are endemic to the basins that drain Caatinga biome. Six species (Apareiodon davisi, Characidium bimaculatum, Hypostomus pusarum, Parotocinclus jumbo, P. spilosoma and Pimelodella enochi) are endemic to the MNCE. Parotocinclus spilosoma and Pimelodella enochi are endemic to Paraíba do Norte River drainage, to which the water bodies of the studied regions belong (Reis et al. 2003, Rosa et al. 2003, Buckup et al. 2007). Studies on the biology of these endemic species that address adaptations in intermittent rivers such as Paraíba do Norte River are unknown, which makes it difficult to predict environmental impacts that changes in the hydrological regime may cause to them after the river transposition. However, special heterogeneity created from different hydrological phases and environmental variables (characteristics from the intermittent rivers) are important factors in the maintenance of a rich and mutable ichthyofauna as it decreases the comprehensive pattern of species dominance. Formation of pools of a variety of sizes and shapes in riverbeds increase fish resilience after flooding as many species use them as a habitat for reproduction (Medeiros \& Maltchick 2001, Barbosa et al. 2012).

According to Maltchik (1999), fish diversity in rivers of the semi-arid region shows an inverse relationship with the hydrological stability, meaning that rivers of greater hydrological stability with minimal seasonal variability have lower rates of biological diversity than rivers with a more instable 

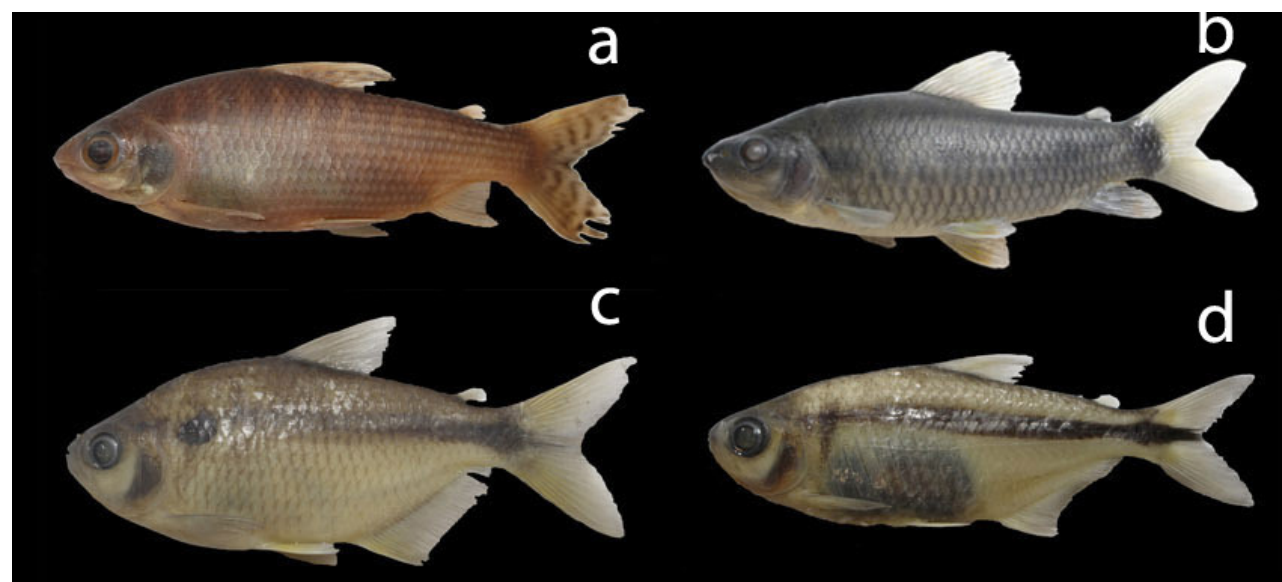

e
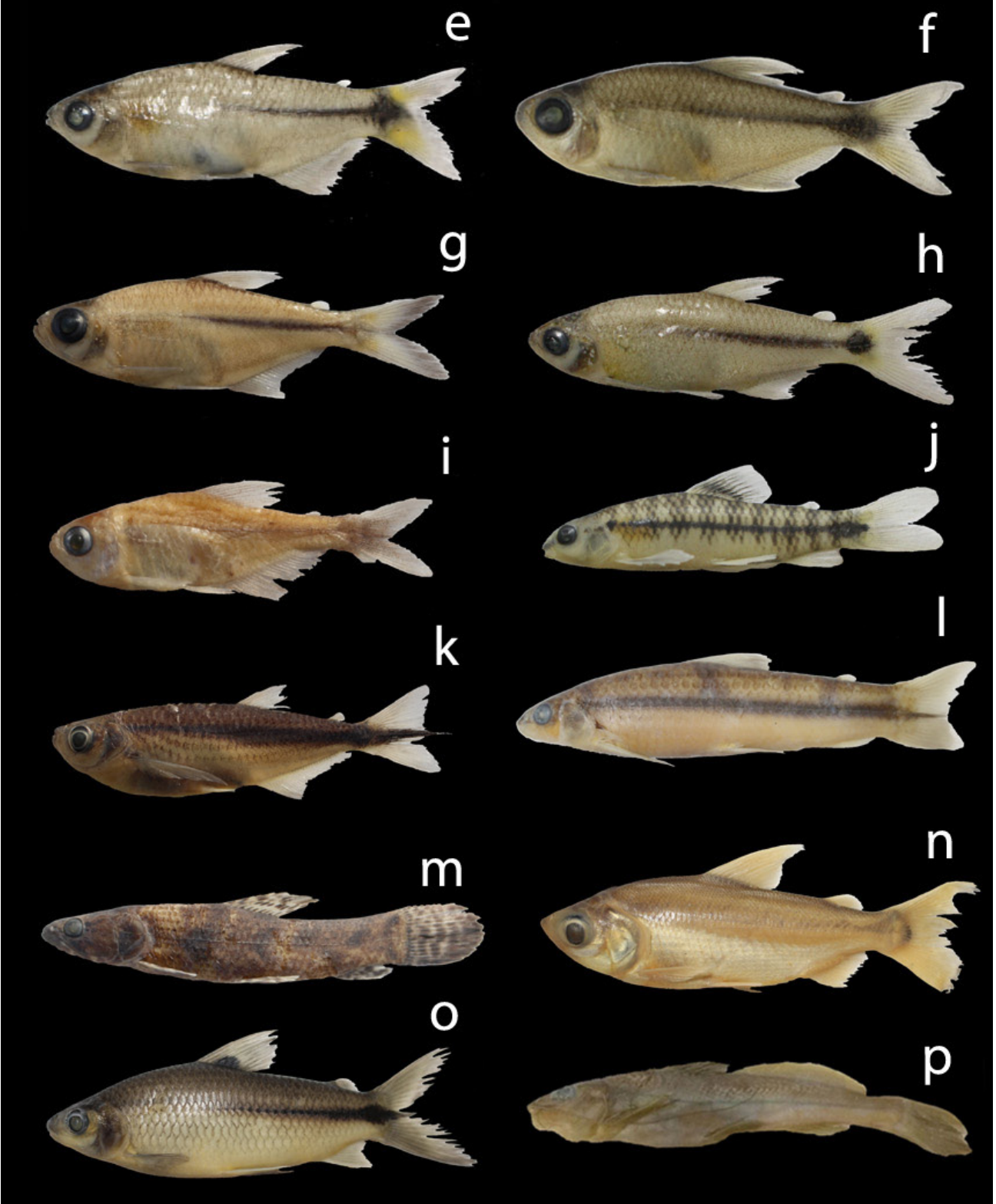

Figure 4. Fishes from the sampled areas of the Argemiro Figueiredo and Epitácio Pessoa reservoirs and their respective downstream areas. a) Prochilodus brevis, $120.5 \mathrm{~mm} \mathrm{SL}$; b) Leporinus piau, $101.2 \mathrm{~mm} \mathrm{SL}$; c) Astyanax aff. bimaculatus, $62.1 \mathrm{~mm}$ SL; d) Astyanax aff. fasciatus, $66.7 \mathrm{~mm}$ SL; e) Compsura heterura, $38.4 \mathrm{~mm}$ SL; f) Hemigrammus rodwayi, $26.2 \mathrm{~mm} \mathrm{SL}$; g) Hemigrammus marginatus, $34.7 \mathrm{~mm} \mathrm{SL}$; h) Serrapinnus heterodon, $35.2 \mathrm{~mm}$ SL; i) Hyphessobrycon parvellus, 21.4 mm SL; j) Characidium bimaculatum, $30.3 \mathrm{~mm} \mathrm{SL}$; k) Triportheus signatus, $84.5 \mathrm{~mm} \mathrm{SL}$;) Apareiodon davisi, $75.4 \mathrm{~mm}$ SL; m) Hoplias cf. malabaricus, $92.7 \mathrm{~mm}$ SL; n) Psectrogaster rhomboides, $140.5 \mathrm{~mm} \mathrm{SL}$; o) Steindachnerina notonota, $96.5 \mathrm{~mm}$ SL; p) Pimelodella enochi, $175.3 \mathrm{~mm}$ SL. 


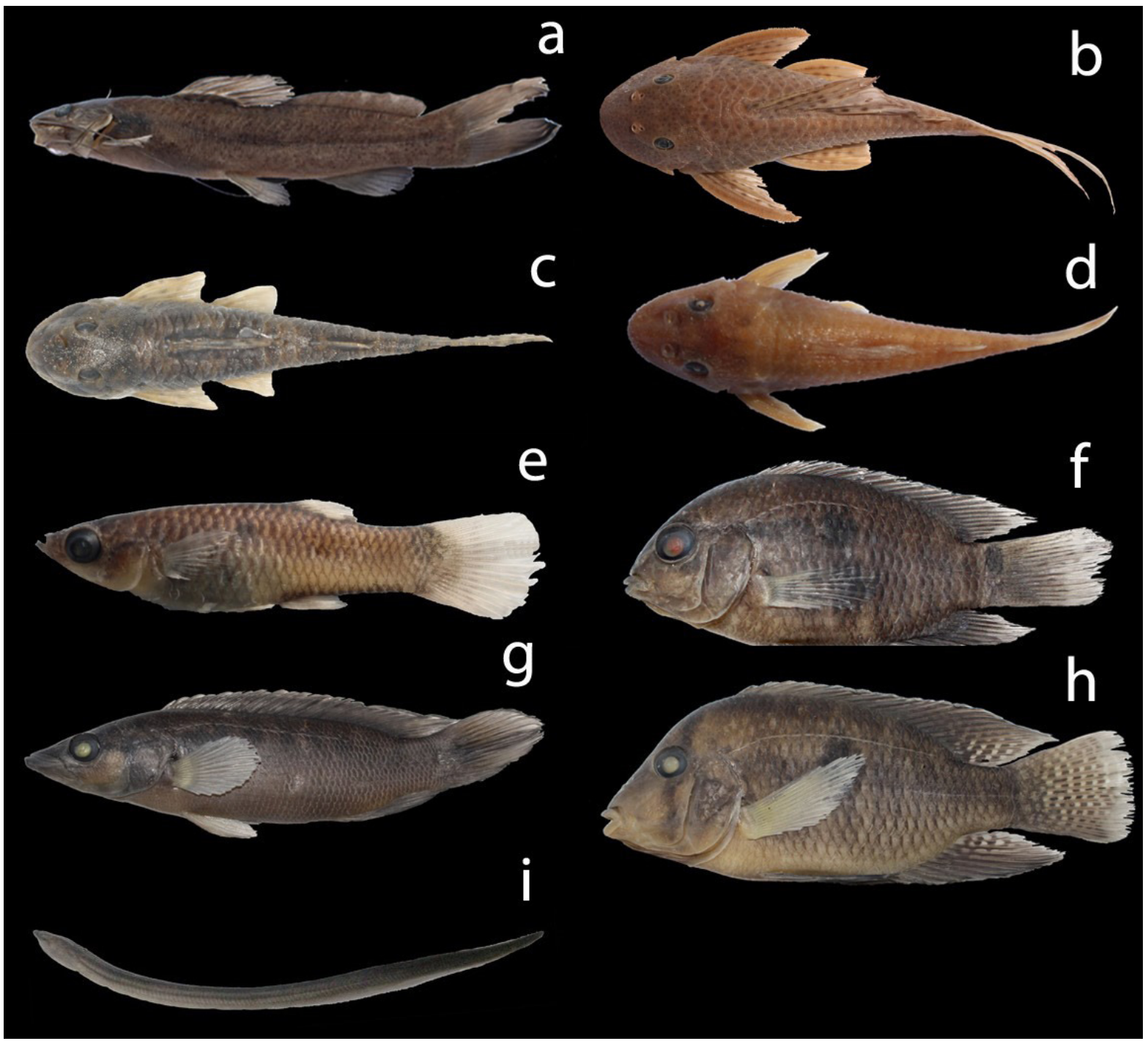

Figure 5. Fishes from the sampled areas of the Argemiro Figueiredo and Epitácio Pessoa reservoirs and their respective downstream areas. a) Rhamdia quelen, 129.1 mm SL; b) Hypostomus pusarum, $124.5 \mathrm{~mm}$ SL; c) Parotocinclus jumbo, $53.6 \mathrm{~mm} \mathrm{SL}$; d) Parotocinclus spilosoma, $38.1 \mathrm{~mm}$ SL; e) Poecilia vivipara, $27.1 \mathrm{~mm}$ SL; f) Cichlasoma orientale, $74.3 \mathrm{~mm} \mathrm{SL}$; g) Crenicichla menezesi, $89.7 \mathrm{~mm} \mathrm{SL}$; h) Geophagus brasiliensis, $118.4 \mathrm{~mm}$ SL; i) Synbranchus aff. marmoratus., 170.5 mm SL.

hydrology. The author further states that this pattern may be explained by the presence of dominant species in rivers of greatest hydrological stability.

The Northeast region of Brazil is currently undergoing a water transposition process, in which waters of São Francisco River basin, which is characterized by a perennial regime, will be artificially connected to the four largest basins of the MNCE that have an intermittent regime. In addition to Paraíba do Norte basin, the watersheds of the Apodi-Mossoró (Rio Grande do Norte), Jaguaribe (Ceará) and Piranhas-Açu Rivers (Paraíba and Rio Grande do Norte) will also receive water from São Francisco River basin through two main channels (Pittock et al. 2009). The transposition of water from the São Francisco basin to MNCE basins may cause changes in species composition, structure and dynamics of these ecosystem fish communities. Taxonomic studies such as the current study are crucial for comparative reevaluation post-transposition. The study of the ichthyofauna of Argemiro de Figueiredo and Epitácio Pessoa Reservoirs and their downstream areas improved the knowledge of fish diversity from Paraíba do Norte River basin, reinforcing subsidies for environmental protection and conservation of its watersheds. Understanding the local ichthyofauna and their ecosystems is essential for assessing future impacts caused by the transposition of São Francisco River as an example of direct anthropic action as well as by introducing exotic species.

\section{Acknowledgements}

We thank all members of Laboratório de Ecologia Aquática from Universidade Estadual da Paraíba (UEPB), especially Patricia Cruz for helping with field work.

\section{Author Contributions}

All authors contributed by collecting specimens, and writing this manuscript. SYLC and TPAR identified the species.

\section{Conflicts of interest}

The authors declare that have no conflict of interest related to the publication of this manuscript. 


\section{References}

AESA. http://site2.aesa.pb.gov.br/aesa/volumesAcudesdomestodo=preparaUltimo sVolumesPorMunicipio (the last access in 04/12/2015).

AGASSIZ, L. \& AGASSIZ, E.C. 1938. Viagem ao Brasil: 1865-1866. São Paulo, Trad. de Edgar Siissekind de Mendonça.

ALMEIDA, V.L.L., RESENDE, E.K. \& VAZZOLER, A.E. 1997. Feeding patterns in five predatory fishes of the hight Paraná River flooddplain (PR Brazil). Ecol. Freshw. Fish 6(3): 123-133.

ATTAYDE, J.L., OKUN, N., BRASIL, J., MENEZES, R., \& MESQUITA, P. 2007. Impactos da introdução da tilápia do Nilo, Oreochromis niloticus, sobre a estrutura trófica dos ecossistemas aquáticos do bioma caatinga. Oecologia Brasiliensia. 11(3): 450-461.

BARBOSA, J.E.L., MEDEIROS, E.S.F., BRASIL, J., CORDEIRO, R.S., CRISPIM, M.C.B. \& SILVA, G.H.G.S. 2012. Aquatic systems in semi-arid Brazil: limnology and management. Acta Limnol. Bras. 24(1): 103-118.

BENNEMANN, S.T. \& SHIBATTA, O.A. 2002. Dinâmica de uma assembleia de peixes do rio Tibagi. A bacia do rio Tibagi. In (M.E. Medri, E, Bianchini, O.A. Shibatta \& J. A. Pimenta eds). Londrina, M. E. Medri, p.433-442.

BRASIL. 2014. Lista Nacional Oficial de Espécies da Fauna Ameaçada de Extinção - Portaria $N^{\circ} 443$, de 17 de dezembro de 2014. Ministério do Meio Ambiente. Diário Oficial da União, Brasília, Seção 1(245): 121-130.

BRITISKI, H.A. 1972. Peixes de água doce do Estado de São Paulo. In Poluição e Piscicultura. Comissão Interestadual da Bacia Paraná-Uruguai. Faculdade de Saúde Pública da USP, São Paulo, p.79-108.

BRITSKI, H.A., SATO, Y. \& ROSA, A.B.S. 1984. Manual de identificação de peixes da região de Três Marias: com chave de identificação para os peixes da bacia do São Francisco. Brasília, Câmara dos Deputados, Codevasf, Divisão de Piscicultura e Pesca.

BUCKUP, P.A., MENEZES, N.A. \& GHAZZI, M.S. 2007. Catálogo das espécies de peixes de água doce do Brasil. Museu Nacional, Rio de Janeiro.

CÂMARA, J.J.C., RODRIGUES A.M., CAMPOS, E.C., SANTOS, R.A. \& MANDELLI J. 1991. Pesca seletiva do tambiú, Astyanax bimaculatus (Linnaeus, 1758) (Characiformes, Characidade), com a utilização de redes de emalhar, na represa de Ibitinga, rio Tietê, Estado de São Paulo, Brasil. Boletim do Instituto de Pesca. 18: 51-60.

CASTRO, R.M.C., \& VARI R.P. 2004. Detritivores of the South American Fish Family Prochilodontidae (Teleostei: Ostariophysi: Characiformes): a phylogenetic and revisionary study. Smithsonian Contributions and Studies Series, p.622- 189.

DRENNER, R.W., SMITH, J.D. \& THRELKELD, S.T. 1996. Lake trophic state and the limnological effects of omnivorous fish. Hydrobiologia. 319(3): 213-223.

ESCHMEYER, W.N., FRICKE, R. \& VAN DER LAAN, R. (eds). 2017. Catalog of fishes: genera, species, references. http:// research.calacademy.org/research/ ichthyology/catalog/fishcatmain.asp (the last access in 06/02/2017).

FONTANA, C.S., BENCKE, G.A. \& REIS, R.E. 2003. Livro vermelho da fauna ameaçada de extinção no Rio Grande do Sul. Edipucrs, Porto Alegre.

FONTENELE, O. \& PEIXOTO, J.T. 1978. Análise dos resultados de introdução da pescada do Piauí, Plagioscion squamosissimus (Heckel,1840), nos açudes do Nordeste. Boletim Técnico DNOCS. 36(1):85-112.

FOWLER, H.W. 1941. A collection of freshwater fishes obtained in eastern Brazil by Dr. Rodolpho von Ihering. Proceedings of the Academy of Natural Sciences of Philadelphia. 93: 123-199.

GOLDSTEIN, R.J. 1973. Cichlids of the world. T.F.H. Publ. Inc. New Jersey.

GURGEL, J.J.S. \& FERNANDO, C.H. 1994. Fisheries in semi-arid Northeast Brazil with special reference on the role of tilapias. International Review of Hydrobiology. 79(1): 77-94.

GURGEL-LOURENÇO, R.C., SOUSA, W.A., SÁNCHEZ-BOTERO, J.I. \& GARCEZ, D.S. 2013. Ichthyofauna of two reservoirs in the middle Acaraú River basin, Ceará, Northeastern Brazil. Check List. 9(6): 1391-1395.

GURGEL-LOURENÇO, R.C., RODRIGUES-FILHO, C.A.S., ANGELINI, R., GARCEZ, D.S. \& SÁNCHEZ-BOTERO, I.J. 2015. On the relation amongst limnological factors and fish abundance in reservoirs at semiarid region. Acta Limnol. Bras. 27(1): 24-38.

HUBBS, C.L. \& LAGLER K.F. 2006. Fishes of the Great Lakes region. University of Michigan Press.

INSA. http://www.insa.gov.br/ (the last access in 04/12/2015).
KULLANDER, S.O. 1983. A revision of the South American cichlid genus Cichlasoma (Teleostei: Cichlidae). Swedish Museum of Natural History, Sweden.

KULLANDER, S.O. 2003. Family Cichlidae. In Check list of the freshwater fishes of South and Central America (R.E. Reis, S.O. Kullander \& C.J. Ferraris Jr.) Edipucrs, Porto Alegre, p.605-654.

LANGEANI, F., CASTRO, R.M.C., OYAKAWA, O.T., SHIBATTA, O.A., PAVANELLI, C.S. \& CASATTI, L. 2007. Diversidade da ictiofauna do Alto rio Paraná: composição atual e perspectivas futuras. Biota Neotrop. 7(3): 181-197.

LANGEANI, F., BUCKUP, P.A., MALABARBA, L.R., PY-DANIEL, L.H.R., LUCENA, C.A.S., ROSA, R.S., ZUANON, J.A.S., LUCENA, Z.M.S., DE BRITTO, M.R., OYAKAWA, O.T. \& GOMES-FILHO, G. 2009. Peixes de Água Doce. In Estado da arte e perspectivas para a zoologia no Brasil (R.M. Rocha, \& W.A.P. Boeger, orgs.). Ed. UFPR, Curitiba, p.211-230.

LOWE-MCCONNELL, R.L. 1975. Fish communities in tropical freshwaters. Longman London.

LOWE-MCCONNELL, R.H. 1987. Ecological studies in tropical fish communities, Cambridge University Press.

MALABARBA, L.R. \& REIS, R.E. 1987. Manual de técnicas para a preparação de coleções zoológicas. Sociedade Brasileira de Zoologia, Campinas. 36: 1-14.

MALTCHIK, L. 1996. Nossos rios temporários, desconhecidos, mas essenciais. Ciências Hoje. 21(122): 64-65.

MALTCHIK, L. 1999. Ecologia de Rios Intermitentes Tropicais. In Perspectivas da Limnologia no Brasil (M.L.M. Pompêo, ed.). Gráfica e Editora União. São Luís.

MARINHO, R.S.A., TORELLI, J.E.R.S., SILVA, A.S. \& RIBEIRO, L.L. 2006 Biodiversidade de peixes do semi-árido paraibano. Revista de Biologia e Ciências da Terra. (1): 112-121.

MONTENEGRO, A. K. A., TORELLI, J. E. R., CRISPIM, M. C., HERNÁNDEZ, M. I. M. \& MEDEIROS, A.M.A. 2012. Ichthyofauna diversity of Taperoá II reservoir, semi-arid region of Paraíba, Brazil. Braz. J. Biol. 72(1): 113-120.

MEDEIROS, E.S. \& MALTCHIK, L. 2001. Fish assemblage stability in an intermittently flowing stream from the Brazilian semiarid region. Austral Ecology. 26(2): 156-164

MEDEIROS, P.H.A., GÜNTNER, A., FRANCKE, T., MAMEDE, G.L. \& ARAÚJO, J.C. 2010. Modelling spatio-temporal patterns of sediment yield and connectivity in a semi-arid catchment with the WASA-SED model. Hydrol Sci. J. 55(4): 636-648.

NELSON, J.S. 2006. Fishes of the World. 4. ed. New Jersey: John Wiley \& Sons

NOVAES, J.L.C., MOREIRA, S.I.L., FREIRE, C.E.C., SOUSA, M.M.O. \& COSTA, R.S. 2013. Fish assemblage in a semi-arid Neotropical reservoir: composition, structure and patterns of diversity and abundance. Braz. J. Biol. 74(2): 290-301.

PAIVA, M.P. 1978. A ictiofauna das Grandes Represas Brasileiras. Revista DAE 38(116): 49-57.

PAIVA, R.E.C., LIMA, S.M.Q., RAMOS, T.P.A. \& MENDES, L. 2014. Fish fauna of Pratagi River coastal microbasin, extreme north Atlantic Forest, Rio Grande do Norte State, northeastern Brazil. Check List. 10(5): 968-975.

PARAÍBA, SECRETARIA DE PLANEJAMENTO. 2007. Avaliação da infraestrutura hídrica e do suporte para o sistema de gerenciamento de recursos hídricos do Estado da Paraíba. João Pessoa, SEPLAN.

PAVANELLI, C.S. 2006. New species of Apareiodon (Teleostei: Characiformes: Parodontidae) from the Rio Piquiri, upper Rio Paraná basin, Brazil. Copeia. (2006)1: 89-95.

PEIXOTO, J.T. 1982. Alimento de tucunaré, Cichla ocellaris Bloch \& Scheneider, 1801 no açude Lima Campos, Icó, Ceará, (Actinopterygii, Cichlidae). Colet. de Trab. Técn. DNOCS, Fortaleza, 2: 159-172.

PITTOCK, J., MENG, J. \& CHAPAGAIN, A.K. 2009. Interbasin water transfers and water scarcity in a changing world -a solution or a pipedream? A discussion paper in a burning issue, 2nd, WWF Germany, Frankfurt.

RAMOS, R.T.C., RAMOS, T.P.A., ROSA, R.S., BELTRÃO, G.B.M. \& GROTH, F. 2005. Diversidade de Peixes (Ictiofauna) da bacia do rio Curimataú, Paraíba. In Análise das variações da biodiversidade do bioma caatinga: suporte das estratégias regionais de conservação (F.S. Araujo, M.J.N. Rodal \& M.R.V. Barbosa, eds.). Ministério do Meio Ambiente, Brasília, p. 291-318.

RAMOS, T.P.A. 2012. Ictiofauna de Água Doce da Bacia do Rio Parnaíba. Unpublished Ph.D. Universidade Federal da Paraíba, João Pessoa. 
RAMOS, T.P.A. RAMOS, R.T.C. \& RAMOS, S.A.Q.A. 2014. Ichthyofauna of the Parnaíba River Basin, Northeastern Brazil. Biota Neotrop. 14(3): 1-6. http:// dx.doi.org/10.1590/S1676-06020140039.

REIS, R.E., ALBERT, J.S., DARIO, F. DI., MINCARONE, M.M., PETRY, P. \& ROCHA, L.A. 2016. Fish biodiversity and conservation in South America. J. Fish Biol. 89(1): 12-47. doi:10.1111/jfb.13016.

REIS, R.E., KULLANDER, S.O. \& FERRARIS JR, C.J. 2003. Check list of the freshwater fishes of South and Central America. Edipucrs, Porto Alegre.

REBOUÇAS, A.C., BRAGA, B.B., TUNDISI, J.G. 2006. Águas Doces no Brasil. $3^{\circ}$ ed. São Paulo: Escrituras.

RESENDE, E.K., PEREIRA, R.A.C., ALMEIDA, V.L.L. \& SILVA, A.G. 1996. Alimentação de peixes carnívoros da planície inundável do rio Miranda, Pantanal, Mato Grosso do Sul, Brasil. Embrapa Pantanal.

ROSA, R.S., MENEZES, N.A., BRITSKI, H.A., COSTA, W.J.E. \& GROTH F. 2003. Diversidade, padrões de distribuição e conservação dos peixes da caatinga. In Ecologia e Conservação da Caatinga (I.R. Leal, M. Tabarelli \& J.M.C. Silva eds.). Editora Universitária da Universidade Federal de Pernambuco, Recife, p.135-180.

ROSA, R.S. \& MENEZES, N.A. 1996. Relação preliminar das espécies de peixes (Pisces: Elasmobranchii e Actinopterygii) ameaçadas no Brasil. Revista Brasileira de Zoologia 13 (3): 647-667.

SÁNCHEZ-BOTERO, I.J., REIS, V.C., CHAVES, F.D.N. \& GARCEZ, D. 2013. Fish assemblage of the Santo Anastácio reservoir (Ceará state, Brazil). Bol. Inst. Pesca. 40(1): 1-15.

SATO, Y. \& GODINHO, H. P. 1999. Peixes da Bacia do rio São Francisco. In Estudos ecológicos de comunidades de peixes tropicais (R.H. Lowe-Mcconnell ed.). Edusp, São Paulo, p.401-416.
SEMARH - Secretaria Extraordinária do Meio Ambiente, dos Recursos Hídricos. 2006. Plano Estadual de Recursos Hídricos da Paraíba-PERH-PB. João Pessoa, Resumo Executivo e Atlas.

SILVA, M.J., COSTA, B.G., RAMOS, T.P.A., AURICCHIO, P. \& LIMA, S.M.Q. 2015. Ichthyofauna of the Gurgeia River, Parnaíba River basin, northeastern Brazil. Check List. 11(5): 1765.

SILVA, M.J., RAMOS, T.P.A., DINIZ, V.D., RAMOS, R.T.C. \& MEDEIROS, E.S. F. 2014. Ichthyofauna of Seridó/Borborema: a semi-arid region of Brazil. Biota Neotrop. 14(3): 1-6. (the last access in 17/02/2016).

SILVA, M.A.V. 1987. Atlas climatológico do Estado da Paraíba. Universidade Federal da Paraíba, Núcleo de Meteorologia Aplicada, Paraíba.

SILVA-FILHO, E.G., SANTANA, F.M.S. \& SEVERI, W. 2011. Ictiofauna do reservatório de Duas Unas, bacia do rio Jaboatão, Pernambuco: resultados preliminares da composição e estrutura da assembleia. Revista Brasileira de Ciências Agrárias. 6(2):351-361.

STARLING, F., LAZZARO, X., CAVALCANTI, C. \& MOREIRA, R. 2002. Contribution of omnivorous tilapia to eutrophication of a shallow tropical reservoir: evidence from a fish kill. Freshwater Biol. 47(12): 2443-2452.

VARI, R.P. 1989. Systematics of the Neotropical Characiform genus Psectrogaster Eigenmann and Eigenmann (Pisces, Characiformes). Smithsonian Instituion Press. 481: 1-41.

ZILLER, S.R. \& ZALBA, S. 2007. Propostas de ação para prevenção e controle de espécies exóticas invasoras. Nature and Conservation. 5(2):8-15.

Received: 07/02/2017

Revised: 17/07/2017

Accepted: 18/07/2017

Published online: 14/08/2017 